\title{
Modes of Grouping Students, Segregation and Educational Inequalities. A Longitudinal Analysis of a Cohort of Students in Switzerland
}

\author{
Modos de Agrupación de Estudiantes, Segregación y \\ Desigualdades Educativas. Un Análisis Longitudinal de una \\ Cohorte de Estudiantes en Suiza
}

\author{
Samuel Charmillot* \\ Georges Felouzis
}

University of Geneva, Switzerland

\begin{abstract}
The education system in Geneva, Switzerland, offers two organisationally contrasting modes of grouping students in secondary 1 education. Students either belong to schools which run a segmented system (students are grouped into two streams based on their academic level) or a more integrated system, with heterogeneous classes made up of ability groups for some subjects. Using longitudinal data, this article examines the impact of these two modes of grouping students and of within-school segregation on the way students are oriented in secondary 2 education. The results of a multilevel logistic regression analysis show that students attending the segmented system are less likely to be oriented towards a baccalaureate school, the most selective path of secondary 2 education. They also show that the effects of within-school segregation contribute to reinforcing inequalities between students: the likelihood of attending a baccalaureate school is much lower in classes with a high percentage of students from a disadvantaged background. Finally, they show that the negative effects of school segregation tend to be stronger in the segmented system.
\end{abstract}

Keywords: Segmented school system; Integrated school system; School inequalities; School segregation; Educational policies.

El sistema educativo en Ginebra, Suiza, ofrece dos modos organizativos para agrupar a los estudiantes de educación secundaria 1. Los estudiantes pertenecen a escuelas que tienen un sistema segmentado (se agrupan en dos corrientes según su nivel académico) o un sistema más integrado, con clases heterogéneas compuestas por grupos de habilidades para algunas materias. Utilizando datos longitudinales, este artículo examina el impacto de estos dos modos de agrupar a los estudiantes en la educación secundaria 2 . Los resultados del análisis de regresión logística multinivel muestran que los estudiantes que asisten al sistema segmentado tienen menos probabilidades de estar orientados hacia una escuela de bachillerato, el camino más selectivo de la educación secundaria 2. También muestran que los efectos de la segregación dentro de la escuela contribuyen a reforzar las desigualdades entre los estudiantes: la probabilidad de asistir a una escuela de bachillerato es mucho menor en las clases con un alto porcentaje de estudiantes de origen desfavorecido. Finalmente, muestran que los efectos negativos de la segregación escolar tienden a ser más fuertes en el sistema segmentado.

Descriptores: Sistema escolar segmentado; Sistema escolar integrado; Desigualdades escolares; Segregación escolar; Políticas educativas.

*Contacto: samuel.charmillot@unige.ch

ISSN: $1696-4713$

www.rinace.net/reice/

revistas.uam.es/reice
Recibido: $\quad 15$ de marzo 2020

$1^{\text {a }}$ Evaluación: 28 de abril 2020

$2^{\text {a }}$ Evaluación: 22 de junio 2020

Aceptado: $\quad 9$ de julio 2020 


\section{Introduction}

The aim of this study is to compare different modes of grouping students in compulsory secondary education in Switzerland in order to determine their respective effects on school careers and inequalities. Studies in this area often focus on comparing two modes of grouping students: on the one hand, segmented systems which group students into different streams according to their academic level and, on the other hand, integrated systems which enrol students in heterogeneous classes irrespective of their academic level. In reality, the situation is not nearly as clear cut. For example, in Germany or Switzerland, compulsory secondary education is generally made up of streams, but the extent of this split varies depending on the Länder or the canton (i.e. state) (Hörner et al., 2015). In France, in spite of a supposedly integrated education system, schools differentiate themselves greatly depending on their student composition and the academic level of their students, recreating de facto streams (Felouzis, Fouquet-Chauprade, \& Charmillot, 2019). In many cases, instead of bringing highly segmented and perfectly integrated systems into opposition, many education policies have chosen mixed solutions, trying to take advantage of both systems.

Up until recently, the school district of Geneva, Switzerland, had the specificity of using in parallel a somewhat flexible form of a segmented system -using two different streamsin certain schools and a more integrated system - with heterogeneous classes made up of ability groups for some subjects - in others. This quasi-experimental situation lasted for several years. Using longitudinal data, we followed a cohort of students who spent their secondary 1 education in one or another of these systems and measured the respective effects of these two modes of grouping students on educational achievement and inequalities in educational paths.

\section{Modes of grouping students, segregation and educational inequalities}

Research findings on the impact of the modes of grouping students within schools tend to agree that segmented systems are not particularly effective on the overall population all the whilst increasing inequalities between students (Brunello \& Checchi, 2007; Gamoran, 2010; Oakes, 2005; Woessmann, 2009). Hanushek and Woessmann (2006) compared all the international assessments -those conducted by the International Association for the Evaluation of Educational Achievement (IEA) at the primary school level and by the Organization for Economic Cooperation and Development (OECD) at the secondary school level- in order to study the relationship between early academic segmentation and the extent of educational inequalities in each country. The authors concluded that educational inequalities intensify between primary and secondary school to a much greater extent in countries where secondary education is comprised of streams rather than a unified programme.

Hence, the question that arises concerns the mechanisms responsible for these aggravated inequalities in segmented systems. For Gamoran and his colleagues (1995), it is the logic underlying segmented systems that reinforces inequalities. By separating students into different groups based on their academic level, schools are looking to manage heterogeneity by dividing students into relatively homogeneous units. The aim of this logic is to allow schools to meet their objectives more easily by allocating 'separated tasks 
to specialized subunits' (p. 688). In other words, grouping students in homogeneous streams according to their academic level should enable the academic differences between peers to be considered more effectively, in particular by providing adapted teaching. This is a principle inspired by organisational theory that considers that in a heterogeneous environment, productivity and effectiveness can be improved by segmentation in structurally homogeneous units. Applied to schooling, this logic has its limits because students are considered to be 'raw materials of the school system'. Yet dividing students is far from being a 'neutral act' (p. 689). Selecting students based on their academic level almost mechanically causes a distinction according to social, cultural, racial/ethnic criteria. Therefore, segmented systems prove to be problematic, since their effectiveness goals contradict objectives of equity.

These negative effects of segmented systems on equity have repeatedly been highlighted by research: students from disadvantaged backgrounds and minority groups are more likely to be oriented towards less demanding streams (Felouzis, Charmillot, \& FouquetChauprade, 2011; Lucas, 1999; Lucas \& Berends, 2002; Mickelson, 2003; Oakes, 2005). Their over-representation in the less demanding streams cannot, nevertheless, be solely explained by differences in academic level, since when academic level is controlled for, the effect of socioeconomic status and ethno-racial origin decreases, but does not disappear entirely (Hallinan, 1994). In other words, for the same academic level, disadvantaged and minority group students are significantly more likely to be placed in a less demanding stream.

It therefore appears that segmented systems, by selecting students based on their academic level, also indirectly contribute to increasing social and ethno-racial segregation between students. Yet educational research has since long highlighted the relationship between school or class composition and educational inequalities (Rumberger \& Palardy, 2005; van Ewijk \& Sleegers, 2010a, b). These composition effects may be defined as 'the impact of pupils' aggregated characteristics (socioeconomic status, sociocultural capital, prior achievements, etc.) when these variables have been taken into account at the individual level' (Dumay \& Dupriez, 2007, p. 440). This means that it is not simply the individual characteristics of students that have an impact on their academic success, but also that students with similar characteristics will succeed differently depending on the composition of their school or class (Coleman et al., 1966; Padilla \& Bazán, 2016).

Research on the effects of segregation tends to show that students with comparable characteristics are not as successful if they are schooled in a segregated context (Monseur \& Crahay, 2008; OECD, 2013; van Ewijk \& Sleegers, 2010a, b). Some research, however, provides more nuanced results, highlighting that the effects of segregation may vary depending on the individual characteristics of the students (Schofield, 1995; Weinberg, 1975), especially for students from minority groups, migrant students and socioeconomically disadvantaged students who seem to be more sensitive to the effects of segregation (Charmillot, 2013; Jencks \& Mayer, 1990).

Based on these studies, the relationship between modes of grouping students and educational inequalities seems clear: segmented systems tend to increase not only academic segregation, but also, indirectly, social and migratory segregation, which contributes to increasing inequalities between students. Nevertheless, the issue has not been totally resolved, as some studies present more contrasting, or even contrary, results. The findings of Slavin $(1987,1990,1993)$ bring nuance to the theory that the effects of 
segmented systems are systematically negative, as its consequences also depend on its concrete implementation within a particular context. Reviewing the literature on experimental research at three levels of schooling (primary, secondary 1 and secondary 2), Slavin shows that there is no clear evidence that students in more demanding streams learn more and those in less demanding streams learn less than students in integrated systems. If the quality and quantity of teaching are held constant, the way students are grouped together does not affect their learning. It is therefore important to note the discrepancies between the results of experimental studies and those achieved in situ. The former has the capacity to isolate - through their experimental approach - the effects of the modes of grouping students from all other effects. In reality, division into streams goes hand in hand with other characteristics that are varied and decisive for learning, such as type of programme, training of teachers, teachers' expectations, stigmatisation of weaker students, etc. Thus, it seems that knowing the way in which segmented systems are really organised plays a decisive role in our understanding of their effects on students.

The purpose of this article is to use data collected in the Geneva canton to provide new empirical evidence on the relationship between modes of grouping students, school segregation and inequalities between students. The education system in Geneva has the particularity to offer in parallel, depending on the specific school, a segmented system or an integrated system with ability groups. Going to a school which uses streams or one which does not, in no way depends on the academic level of the students or the academic choices of the families, but solely on the school catchment area one belongs to. Access to one system or the other therefore does not introduce any bias in the composition of the public of students, which makes it possible to reason on the consequences of these two modes of grouping students. The empirical framework for this article is a sample of students in Geneva public schools, finishing their compulsory curriculum during the 2002-03 school year, who participated in the 2003 PISA Suisse study. These students were studied over a four-year period in order to follow their school careers until the end of secondary 2 education. We use multilevel logistic regression analysis on these data in order to estimate the impact of the modes of grouping students (segmented system vs integrated system with ability groups) and of within-school segregation on how students are oriented in the various educational paths of secondary 2 education; we will be focusing on baccalaureate schools, the most selective path of secondary 2 education ${ }^{1}$. Three questions will be addressed with this analysis:

- Does the probability of being in a baccalaureate school in secondary 2 education varies according to the modes of grouping students in secondary 1 education?

- Does the probability of being in a baccalaureate school in secondary 2 education varies according to social and migratory segregation in secondary 1 education?

- Does the impact of the mode of grouping students varies depending on academic, social and migratory segregation in secondary 1 education?

\footnotetext{
${ }^{1}$ Baccalaureate schools lead to further education in Swiss Federal Institutes of Technology and
} universities. 


\section{Method}

The data used for our analysis come from two statistical sources:

- The Geneva schooling database, which takes a census of Geneva students entering the school system. Updated on a yearly basis, this database monitors students throughout their school-life, up until they leave the education system.

- The data from the 2003 PISA Suisse study for the canton of Geneva. This is an oversample of the data from the PISA International study, in which 20000 students from all over Switzerland participated. The difference between the two studies is that the PISA Suisse study questioned students at a given level (last year of secondary 1 education) instead of at a specific age (15 years old). The sample is therefore representative of all students in the last year of their compulsory curriculum in Geneva in 2002-03.

These two databases have a common identification number allowing the students who participated in the 2003 PISA Suisse study to be identified in the school database. We therefore have at our disposal the modes of grouping students at the end of secondary 1 education, a measure of their competences at this time (PISA score in mathematics) and their orientation up until the third year of secondary 2 education.

\subsection{The education system in Geneva}

Because of Switzerland's federal structure, three political bodies share the educational tasks: Confederation (central government), the cantons and the municipalities. Compulsory schooling (primary and secondary 1 education) is mainly under the jurisdiction of the cantons. They are more or less free to organise the education system as they see fit, providing that they meet the general objectives set at the federal level.

\subsubsection{Secondary 1 education}

In Geneva, at the time the data were collected, compulsory education spanned 9 years. Primary school, from year 1 to year 6 (for students aged from 6 to 11) was split into heterogeneous classes, irrespective of academic level. Secondary 1 education lasted for 3 years (year 7 to 9); students were typically between 12 and 15. At this stage, the Geneva education system offered two organisationally contrasting modes of grouping students: entirely dependent on their catchment area, students either belonged to schools which ran a system presented as segmented or a system presented as integrated.

In 17 of the schools, students were grouped in two streams, based on their academic level: the best students were oriented towards classes with high requirements (top stream), whilst the weaker students were oriented towards small size classes with low requirements (bottom stream).

In 3 of the schools, students were grouped in heterogeneous classes; however, certain subjects were divided into ability groups ${ }^{2}$.

The 'segmented' and 'integrated' character of these modes of grouping, however needs to be nuanced, as the way they are organised differs significantly to their official title. Thus,

\footnotetext{
${ }^{2}$ Admission to the different streams, or for the heterogeneous classes to the different ability groups, is principally based on the grades obtained at the end of primary school in the "main subjects' (French, German and mathematics).
} 
in the system considered 'segmented', three quarters of the students (73.7\%) are grouped into the top streams, while the bottom stream enrols only $26,3 \%$ of the students, the academically weaker ones. Far from being totally homogeneous and streamed, the segmented system contributes first and foremost to separating the large majority of students from their peers with learning difficulties. At the same time, the integrated system' only seems to be 'partially integrated' as the teaching of certain key subjects (German and mathematics) is undertaken in ability groups. It is therefore important to distinguish between the 'official' definition of the modes of grouping and the far more complex way in which they actually work in the Geneva education system.

\subsubsection{Secondary 2 education}

After completing their compulsory schooling, the majority of Geneva students head towards secondary 2 education, made up of three educational paths:

- Baccalaureate schools: a four-year academic path which opens the way to university or Swiss Institutes of Technology.

- Vocational training: commonly known as 'apprenticeships', this training provides the acquisition of the necessary skills and knowledge to carry out certain professions. Here we can distinguish between full time vocational training where students accomplish all of their training at a professional school and dual vocational training where students split their time between a training company and school.

- General culture schools (GCS): this path offers general culture education and specific courses in the domains of health, social work, communicationinformation and applied arts. It prepares students for Switzerland's Universities of Applied Sciences and Higher Vocational Schools.

\subsection{Measuring the effect of social and migratory segregation}

In the framework of this article, we are taking into account simultaneously the effect of social and migratory segregation. This choice is motivated by the somewhat specific structure of Geneva's migrant population. With almost $40 \%$ of Geneva students having foreign origins, the education system in Geneva exhibits a very large cultural diversity. However, this migrant population is far from being homogeneous on a socioeconomic level. On the one hand, there are, as in most European countries, socioeconomically disadvantaged migrants. These are essentially 'economic migrants', who have come to Switzerland to work, often in low-skilled jobs. However, at the same time, Geneva is home to many international companies and organisations, hence migrants with a very high socioeconomic and cultural level can also be found.

To measure the social status of the students, we rely on a variable derived from the index of economic, social and cultural status' (ESCS) used in PISA studies. The ESCS index is developed from three variables measuring different dimensions of the family environment:

- The index of parents' social status, which indicates the highest professional status out of both parents based on the International Socio-Economic Index of Occupational Status (ISEI) (Ganzeboom, De Graaf, \& Treiman, 1992).

- The index of home possessions, which indicates the level of family wealth. The household's material, cultural and educational possessions are taken into account. 
- The index of highest educational level of parents. This variable is based on the International Standard Classification of Education (ISCED) drawn up by UNESCO, which differentiates between seven educational levels from preprimary (ISCED 0) to the second stage of tertiary education (ISCED 6) (UNESCO, 2006).

For the analysis, the ESCS index was split into three terciles: disadvantaged students (low ESCS), middle-class students (middle ESCS) and advantaged students (high ESCS).

To determine the migratory status of students, we differentiated between them using both their place of birth and that of their parents. Native students are those born in Switzerland having at least one parent who was born in Switzerland. Second-generation students are those born in Switzerland to parents born abroad. First-generation students are those born abroad to parents born abroad.

By grouping these two variables, we obtain a measure of 'social and migratory status' which distinguishes between native and migrant students according to their socioeconomic status (see table 1). Native students represent $66.1 \%$ of the total students in Geneva, $27.9 \%$ of whom have a high ESCS and $13.5 \%$ of whom have a low ESCS. Second-generation migrants make up $20.4 \%$ of all students: $3.6 \%$ of whom have a high ESCS and $11.1 \%$ of whom have a low ESCS. First-generation migrants make up $13.4 \%$ of the sample: $2.2 \%$ of whom have a high ESCS and $7.1 \%$ of whom have a low ESCS. Almost three quarters of second-generation migrant students have either Portuguese (26.7\%), Italian $(25.1 \%)$ or Spanish (20.9\%) origins. First-generation migrants are mainly students born in Portugal (23.3\%), in one of the countries making up the ex-Yugoslavia (23.5\%) and in Africa (16.9\%).

Table 1 gives detailed information on the social and migratory composition of the two modes of grouping students in secondary 1 education (segmented or integrated system) and of the different paths undertaken in secondary 2 education.

In secondary 1 education, students' social and migratory characteristics are very similar in both systems. However, it should be noted that the integrated system is made up of slightly less native students with a high ESCS (25.6\% compared to 28.4\% in the segmented system) and more first-generation students (17.6\% compared to $12.5 \%$ ). Despite these slight differences, the two systems can be considered as schooling comparable students in terms of their social and migratory characteristics. Within the segmented system, however, large differences can be observed between the top stream and the bottom stream. Generally, the more advantaged a student's social status is, the more likely it is that he or she will be in a top stream. Nevertheless, the migratory status also needs to be taken into consideration as with an equivalent social status, native students are more present in the top stream than their peers with an immigrant background. Thus, native students with a high ESCS appear to be rather over-represented in the top stream, accounting for $34.3 \%$ of the students in this stream. Conversely, students with a low ESCS are over-represented in the bottom stream, whether they be native (20.9\%), second-generation (20.9\%) or first-generation students (13.3\%). 
Table 1. Modes of grouping students in the last year of secondary 1 education and path undertaken in the third year of secondary 2 education, depending on social and migratory status

\begin{tabular}{|c|c|c|c|c|c|c|c|c|c|c|}
\hline & \multicolumn{2}{|c|}{$\begin{array}{l}\text { TOTAL No OF } \\
\text { STUDENTS }\end{array}$} & \multicolumn{4}{|c|}{$\begin{array}{l}\text { MODES OF GROUPING STUDENTS IN } \\
\text { SECONDARY } 1 \text { EDUCATION }\end{array}$} & \multicolumn{4}{|c|}{ PATH IN SECONDARY 2 EDUCATION } \\
\hline & \multirow[b]{2}{*}{$\mathbf{N}$} & \multirow[b]{2}{*}{$\%$} & \multicolumn{3}{|c|}{ Segmented system } & \multirow[b]{2}{*}{$\begin{array}{l}\text { Integrated } \\
\text { system }\end{array}$} & \multirow[b]{2}{*}{$\begin{array}{l}\text { Baccalaureate } \\
\text { schools }\end{array}$} & \multirow[b]{2}{*}{$\begin{array}{l}\text { Full-time } \\
\text { vocational } \\
\text { training }\end{array}$} & \multirow[b]{2}{*}{$\begin{array}{l}\text { Dual } \\
\text { vocational } \\
\text { training }\end{array}$} & \multirow[b]{2}{*}{ GCS } \\
\hline & & & $\begin{array}{l}\text { Top } \\
\text { stream }\end{array}$ & $\begin{array}{l}\text { Bottom } \\
\text { stream }\end{array}$ & $\begin{array}{c}\text { Total } \\
\text { segmented } \\
\text { system }\end{array}$ & & & & & \\
\hline Native students with a low ESCS & 419 & $13.5 \%$ & $11.9 \%$ & $20.9 \%$ & $13.8 \%$ & $12.0 \%$ & $9.1 \%$ & $15.6 \%$ & $21.4 \%$ & $15.3 \%$ \\
\hline Native students with a middle ESCS & 766 & $24.7 \%$ & $26.2 \%$ & $18.9 \%$ & $24.7 \%$ & $25.2 \%$ & $22.8 \%$ & $25.7 \%$ & $24.8 \%$ & $29.7 \%$ \\
\hline Native students with a high ESCS & 864 & $27.9 \%$ & $34.3 \%$ & $6.7 \%$ & $28.4 \%$ & $25.6 \%$ & $42.5 \%$ & $19.5 \%$ & $10.9 \%$ & $14.4 \%$ \\
\hline $\begin{array}{l}\text { Second-generation students with a low } \\
\text { ESCS }\end{array}$ & 343 & $11.1 \%$ & $8.4 \%$ & $20.9 \%$ & $11.1 \%$ & $11.0 \%$ & $6.6 \%$ & $14.2 \%$ & $19.0 \%$ & $10.9 \%$ \\
\hline $\begin{array}{l}\text { Second-generation students with a } \\
\text { middle ESCS }\end{array}$ & 178 & $5.7 \%$ & $5.3 \%$ & $8.3 \%$ & $5.9 \%$ & $4.8 \%$ & $4.9 \%$ & $6.4 \%$ & $4.5 \%$ & $9.2 \%$ \\
\hline $\begin{array}{l}\text { Second-generation students with a high } \\
\text { ESCS }\end{array}$ & 112 & $3.6 \%$ & $4.0 \%$ & $2.3 \%$ & $3.6 \%$ & $3.7 \%$ & $3.8 \%$ & $3.8 \%$ & $2.6 \%$ & $3.7 \%$ \\
\hline $\begin{array}{l}\text { First-generation students with a low } \\
\text { ESCS }\end{array}$ & 221 & $7.1 \%$ & $5.0 \%$ & $13.3 \%$ & $6.8 \%$ & $8.9 \%$ & $3.1 \%$ & $10.6 \%$ & $10.3 \%$ & $10.9 \%$ \\
\hline $\begin{array}{l}\text { First-generation students with a } \\
\text { middle ESCS }\end{array}$ & 126 & $4.1 \%$ & $2.9 \%$ & $7.2 \%$ & $3.8 \%$ & $5.2 \%$ & $3.6 \%$ & $4.1 \%$ & $5.1 \%$ & $4.2 \%$ \\
\hline $\begin{array}{l}\text { First-generation students with a high } \\
\text { ESCS }\end{array}$ & 67 & $2.2 \%$ & $2.0 \%$ & $1.4 \%$ & $1.9 \%$ & $3.5 \%$ & $3.6 \%$ & $0.3 \%$ & $1.3 \%$ & $1.7 \%$ \\
\hline Total & 3096 & $100.0 \%$ & $100.0 \%$ & $100.0 \%$ & $100.0 \%$ & $100.0 \%$ & $100.0 \%$ & $100.0 \%$ & $100.0 \%$ & $100.0 \%$ \\
\hline
\end{tabular}

Note: Computed by the authors. 
These findings show that the segmented system produces segregation between classes (within-school segregation): classes of the top stream are characterised by an overrepresentation of socioeconomically advantaged students, in particular native students with a high ESCS, whereas classes of the bottom stream are predominantly made up of disadvantaged students, whether natives or migrants.

Being in the top or bottom stream in secondary 1 education largely determines the path undertaken in secondary 2 education. As a result, native students with a high ESCS are overrepresented in baccalaureate schools $(42.5 \%)$. On the contrary, vocational training concentrates a large proportion of the students with a low ESCS. For example, more than half of the students on dual vocational training have a low ESCS (21.4\% natives, $19 \%$ second-generation and $10.3 \%$ first-generation students).

Table 2. Within-school segregation in the last year of secondary 1 education depending on students' social and migratory status and the modes of grouping students (variance ratio)

\begin{tabular}{lccc}
\hline & $\begin{array}{c}\text { SEgMENTED } \\
\text { SYSTEM }\end{array}$ & $\begin{array}{c}\text { INTEGRATED } \\
\text { SYSTEM }\end{array}$ & $\begin{array}{c}\text { SEGMENTED AND } \\
\text { INTEGRATED } \\
\text { SYSTEM TOGETHER }\end{array}$ \\
\hline Native students with a low ESCS & $8.5 \%$ & $5.7 \%$ & $8.1 \%$ \\
Native students with a middle ESCS & $17.8 \%$ & $13.2 \%$ & $17.1 \%$ \\
Native students with a high ESCS & $7.3 \%$ & $5.8 \%$ & $7.1 \%$ \\
Second-generation students with a low ESCS & $10.8 \%$ & $7.8 \%$ & $10.3 \%$ \\
Second-generation students with a middle & $12.1 \%$ & $5.5 \%$ & $11.2 \%$ \\
ESCS & $4.7 \%$ & $5.0 \%$ & $4.7 \%$ \\
Second-generation students with a high ESCS & $11.3 \%$ & $7.2 \%$ & $10.6 \%$ \\
First-generation students with a low ESCS & $8.8 \%$ & $7.8 \%$ & $8.7 \%$ \\
First-generation students with a middle ESCS & $7.0 \%$ & $8.9 \%$ & $7.7 \%$ \\
First-generation students with a high ESCS & & & \\
\hline
\end{tabular}

Note: Computed by the authors.

A more accurate measure of the extent of within-school segregation in secondary 1 education can be given by using segregation indexes (Murillo, 2016; Murillo \& MartínezGarrido, 2019). We use the variance ratio ${ }^{3}$ (James \& Taeuber, 1985) which may be interpreted as a measure of the relative difference between the observed exposition of a group $x$ to a group $y$ and their expected exposition, if the two groups had been equally distributed in spatial units. The variance ratio varies between 0 and $100 \%$; the maximum value indicates that the group is totally isolated in spatial units. In the framework of our data, this means that the higher the value of the variance ratio, the more likely the members of a given group are to be together in the same class.

Table 2 shows that within-school social and migratory segregation is relatively low in Geneva since the variance ratio never exceeds $17.1 \%$. However, it is not identical for all groups of students: it is more pronounced for native students with a middle ESCS ( $V=$ $17.1 \%)$, for second-generation students with a middle ESCS ( $V=11.2 \%)$, as well as for

${ }^{3}$ The variance ratio $(V)$ is calculated using the following formula: $V=\sum t_{i}\left(p_{i}-P\right)^{2} / T P(1-P)$, where $\mathrm{T}$ stands for the total population, $\mathrm{P}$ is the population of a group, $t_{i}$ is the total population in a spatial unit $i$ and $p_{i}$ is the population of a group in the spatial unit $i$. 
second and first-generation students with a low ESCS (10.3\% and 10.6\% respectively). The comparison between the two modes of grouping students indicates that within-school segregation is higher in the segmented system. Large differences can be noted for secondgeneration students with a middle ESCS, as well as for all the students with a low ESCS, irrespective of their migratory status, who are clearly more segregated in the segmented system than in the integrated system. As we have seen, it is particularly these disadvantaged students who are over-represented in the classes of the bottom stream. It is therefore they who should suffer most from the negative effects of the segregation produced by streaming.

\subsection{Analytical strategy}

We use multilevel logistic regression analysis which enables us to examine the relationship between an independent binary variable and several explanatory variables. We are therefore reasoning on the probability of being oriented towards one of the different paths of secondary 2 education. Multilevel modelling allows the hierarchical structure of the data to be considered, in order to have a reliable estimate of the contextual effects. Indeed, when data are hierarchical -individuals (level 1) are grouped in larger units (level 2)- one can suppose that there will be a correlation between residuals within the groups. This means that observations nested within the same group 'are likely to be experientially and demographically similar to each other, but different from observations in other groups' (Bickel, 2007, pp. 61-62). In the framework of our data, level 1 represents the students in Geneva public schools $(\mathrm{n}=1643)^{4}$; level 2 represents the class in which students are enrolled in secondary 1 education $(\mathrm{n}=94)^{5}$.

\section{Dependent variables}

Our analysis focuses on the most demanding and selective secondary 2 education path: baccalaureate schools. Our dependant variable is dichotomous: 1 represents the students in baccalaureate schools and $O$ represents their peers in another path (vocational training or GCS). We analyse the probability of being in a baccalaureate school, three years after the end of secondary 1 education. We focus on medium-term orientations -rather than immediately after the end of secondary 1 education- in order to take mid-course reorientations into account, these being commonplace. Indeed, only $62.1 \%$ of students who start secondary 2 education in a baccalaureate school actually have an uninterrupted career. Their peers either repeat a year or change path to a less demanding one.

\section{Independent variables}

Individual characteristics of students are taken into account using the following variables: gender, social and migratory status, language spoken, years repeated and age. Their initial level of competence is measured by the PISA score in mathematics in the last year of secondary 1 education ${ }^{6}$.

\footnotetext{
4 These are unweighted numbers. Due to the sampling method used in PISA, it is necessary to weigh the sample for it to be representative of the population. Our analysis is based on 1643 pupils, representative of 3138 pupils. For more details on the weighing method used in PISA, see OECD (2005).

${ }^{5}$ Our analysis does not include 'workshop classes' aimed at students with extensive educational difficulties nor 'reception classes' aimed at integrating migrant students newly arrived in Geneva. ${ }^{6}$ PISA studies measure competences in reading, mathematics and science. We focus on mathematics as it is the major domain of the 2003 PISA study. This means that two thirds of
} 
Along with these individual variables, we also have class-level control variables. The effect of within-school segregation is taken into account by measuring the social and migratory composition of classes. We selected three variables: average percentage of native students with a low ESCS per class, average percentage of second-generation students with a low ESCS per class and average percentage of first-generation students with a low ESCS per class. We assume that being in a class with a high proportion of native or migrant students from a disadvantaged social background has a significant effect on one's chances of continuing on to a baccalaureate school.

We also included other variables measuring the composition of the class (average percentage of boys per class, average percentage of students who repeated a year per class, average age of the class and average mathematics score per class), as well as variables measuring several dimensions of the class climate: the index of teacher-student relations, which measures the students' perception of their relationship with their teachers; the teacher support index, which is based on the students' perception of whether their teachers support them or not; the index of disciplinary climate, which evaluates whether the environment of the class is adapted to learning.

Finally, we have included a variable which differentiates between the modes of grouping students in classes. We assume that -all other things being equal- being at school in the segmented system has a negative effect on one's chances of being oriented into a baccalaureate school.

Using these variables (see table A1 in Appendix), we have built four regression models.

- Model o (empty) allows to decompose between level 1 variance (individual) and level 2 variance (class).

- Model 1 includes the effect of students' individual characteristics.

- Model 2 introduces the effect of within-school segregation.

- Model 3 includes the effect of class composition and classroom climate.

- Model 4 draws on the effect of the modes of grouping students in classes.

\section{Results}

The empty model allows to determine the proportion of the variance explained at the class level (level 2). The class explains $36.3 \%$ of the total variance in the probability of being in a baccalaureate school three years after the end of secondary 1 education? ${ }^{7}$.

When we include the effect of students' individual characteristics (model 1), the level 2 variance only accounts for $14.5 \%$ of the total variance, which indicates that a large part of the class effect is linked to students' individual characteristics. The effect of social and migratory status is significant for native students with a middle $\operatorname{ESCS}(\mathrm{OR}=.443, \mathrm{p}<$

testing time is given over to mathematics, whilst reading and science are subject to briefer assessments.

${ }^{7}$ To calculate the level 2 variance, we use the intraclass correlation coefficient (ICC). It is given by the following formula: ICC $=\frac{\tau_{0}^{2}}{\tau_{0}^{2}+\pi^{2} / 3}$, where $\tau_{0}^{2}$ represents the random intercept variance. For more details, see Snijders and Bosker (2012). 
$.001)$, as well as for native students $(\mathrm{OR}=.319, \mathrm{p}<.001)$, second-generation students $(\mathrm{OR}=.243, \mathrm{p}<.001)$ and first-generation students $(\mathrm{OR}=.210, \mathrm{p}<.001)$ with a low ESCS. The effect of the PISA score in mathematics is also significant $(\mathrm{OR}=2.936, \mathrm{p}<$ .001 ), which highlights the key role of the initial level of competence on the orientation in secondary 2 education.

Model 2 takes the effect of within-school segregation into account, which is measured by taking the average percentage of native, second-generation and first-generation students with a low ESCS per class. Adding in the variables that measure the social and migratory composition of the classes contributes to reducing the level 2 variance, which only explains $10.5 \%$ of the total variance. Odds-ratio indicate a negative and significant effect of the average percentage of native and second-generation students with a low ESCS per class. The likelihood of being in a baccalaureate school decreases by 1.67 each time the percentage of native students with a low ESCS per class increases by a standard deviation $(\mathrm{OR}=.596, \mathrm{p}<.001)$ and by 1.57 each time the percentage of second-generation students with a low ESCS increases $(\mathrm{OR}=.636, \mathrm{p}<.001)$. The percentage of first-generation students with a low ESCS per class does not have a significant effect $(\mathrm{OR}=.862, \mathrm{p}=$ $.222)$.

Model 3 aims to test the effect of other variables measuring class composition and classroom climate. Introducing these variables into the regression model further reduces the class variance, which now only explains $4.7 \%$ of the total variance. Only one of these level 2 variables has a significant effect: the average PISA score in mathematics per class $(\mathrm{OR}=1.545, \mathrm{p}=.018)$.

Model 4 takes into account the effect of the modes of grouping students in classes. All other things being equal, students from the segmented system are 1.6 times less likely to be in a baccalaureate school $(\mathrm{OR}=.625, \mathrm{p}=.035)$. This shows that the integrated system is more effective than the segmented system as its students have a higher probability of being in a baccalaureate school.

Model 4b (see table A2 in Appendix) allows for a more thorough look at the effects of the segmented system by differentiating between top stream students and their bottom stream peers. There is a significant effect for bottom stream students: they are 20 times less likely than their peers from the integrated system to be in a baccalaureate school (OR $=.048, \mathrm{p}<.001)$.

Figure 1 gives the predicted probability of being in a baccalaureate school depending on the modes of grouping students in classes and the PISA score in mathematics. 
Table 3. Probability of being in a baccalaureate school, three years after the end of secondary 1 education. Multilevel logistic regression analysis (oddsratio)

\begin{tabular}{|c|c|c|c|c|c|c|}
\hline & & MODEL 0 & MODEL 1 & MODEL 2 & MODEL 3 & MODEL 4 \\
\hline \multicolumn{2}{|l|}{ Constant } & $0.630 * *$ & $0.691^{* *}$ & $0.583^{* *}$ & $0.555^{* *}$ & 0.796 \\
\hline \multirow{9}{*}{$\begin{array}{l}\text { Social and migratory } \\
\text { status }\end{array}$} & Native students with a low ESCS & & $0.319^{* * *}$ & $0.397 * * *$ & $0.38 * * *$ & $0.384^{* * *}$ \\
\hline & Native students with a middle ESCS & & $0.443^{* * *}$ & $0.467 * * *$ & $0.466^{* * * *}$ & $0.469^{* * *}$ \\
\hline & Native students with a high ESCS & & $0.243^{* * *}$ & $0.304^{* * * *}$ & $0.278^{* * *}$ & $0.281^{* * * *}$ \\
\hline & Second-gen. students with a low ESCS & & 0.619 & 0.688 & 0.696 & 0.712 \\
\hline & Second-gen. students with a middle ESCS & & 0.682 & 0.738 & 0.688 & 0.7 \\
\hline & Second-gen. students with a high ESCS & & $0.210^{* * *}$ & $0.256^{* *}$ & $0.210^{* * * *}$ & $0.214^{* * *}$ \\
\hline & First-gen. students with a low ESCS & & 0.851 & 1.009 & 1.067 & 1.096 \\
\hline & First-gen. students with a middle ESCS & & 2.073 & 2.373 & 2.586 & 2.672 \\
\hline & First- gen. students with a high ESCS & & ref. & ref. & ref. & ref. \\
\hline \multirow{2}{*}{ Sex } & Girls & & $3.161 * * *$ & $3.158^{* * * *}$ & $2.974 * * *$ & $2.959^{* * * *}$ \\
\hline & Boys & & ref. & ref. & ref. & ref. \\
\hline \multirow{2}{*}{ Language spoken } & Other languages & & 1.394 & 1.459 & $1.584 *$ & $1.562 *$ \\
\hline & French & & ref. & ref. & ref. & ref. \\
\hline \multirow{2}{*}{ Years repeated } & Did repeat a year & & $0.310^{* * * *}$ & $0.313^{* * * *}$ & $0.330 * *$ & $0.332^{* *}$ \\
\hline & Did not repeat a year & & ref. & ref. & ref. & ref. \\
\hline Age & & & 0.858 & 0.85 & 0.899 & 0.899 \\
\hline PISA score in mathem & atics & & $2.936^{* * * *}$ & $2.757^{* * * *}$ & $2.524 * * *$ & $2.512^{* * * *}$ \\
\hline \multirow{3}{*}{$\begin{array}{l}\text { Social and migratory } \\
\text { composition of } \\
\text { classes }\end{array}$} & $\begin{array}{l}\text { Average percentage of native students with a low } \\
\text { ESCS per class }\end{array}$ & & & $0.596^{* * * *}$ & $0.723^{*} *$ & $0.731 * *$ \\
\hline & $\begin{array}{l}\text { Average percentage of second-gen. students with a low } \\
\text { ESCS per class }\end{array}$ & & & $0.636^{* * * *}$ & $0.780^{*}$ & 0.813 \\
\hline & $\begin{array}{l}\text { Average percentage of first-gen. students with a low } \\
\text { ESCS per class }\end{array}$ & & & 0.862 & 1.236 & 1.228 \\
\hline
\end{tabular}




\begin{tabular}{lcc}
\hline Average percentage of boys per class & 0.934 & 0.954 \\
\hline Average percentage of students who repeated a year per class & 1.221 & 1.203 \\
\hline Average age of the class & 0.776 & 0.776 \\
\hline Average mathematics score per class & $1.545^{*}$ & $1.714^{* * *}$ \\
\hline Average score per class on the index of teacher-student relations & 1.172 & 1.225 \\
\hline Average score per class on the teacher support index & 0.846 & 0.85 \\
\hline Average score per class on the index of disciplinary climate & 1.087 \\
\hline $\begin{array}{l}\text { Modes of grouping } \quad \text { Segmented system } \\
\text { students }\end{array}$ & 1.065 \\
\hline Proportion of total variance explained at the class level (level 2$)$ - ICC & $0.625^{*}$ \\
\hline Note Con & ref. \\
\hline
\end{tabular}

Note: Computed by the authors. 


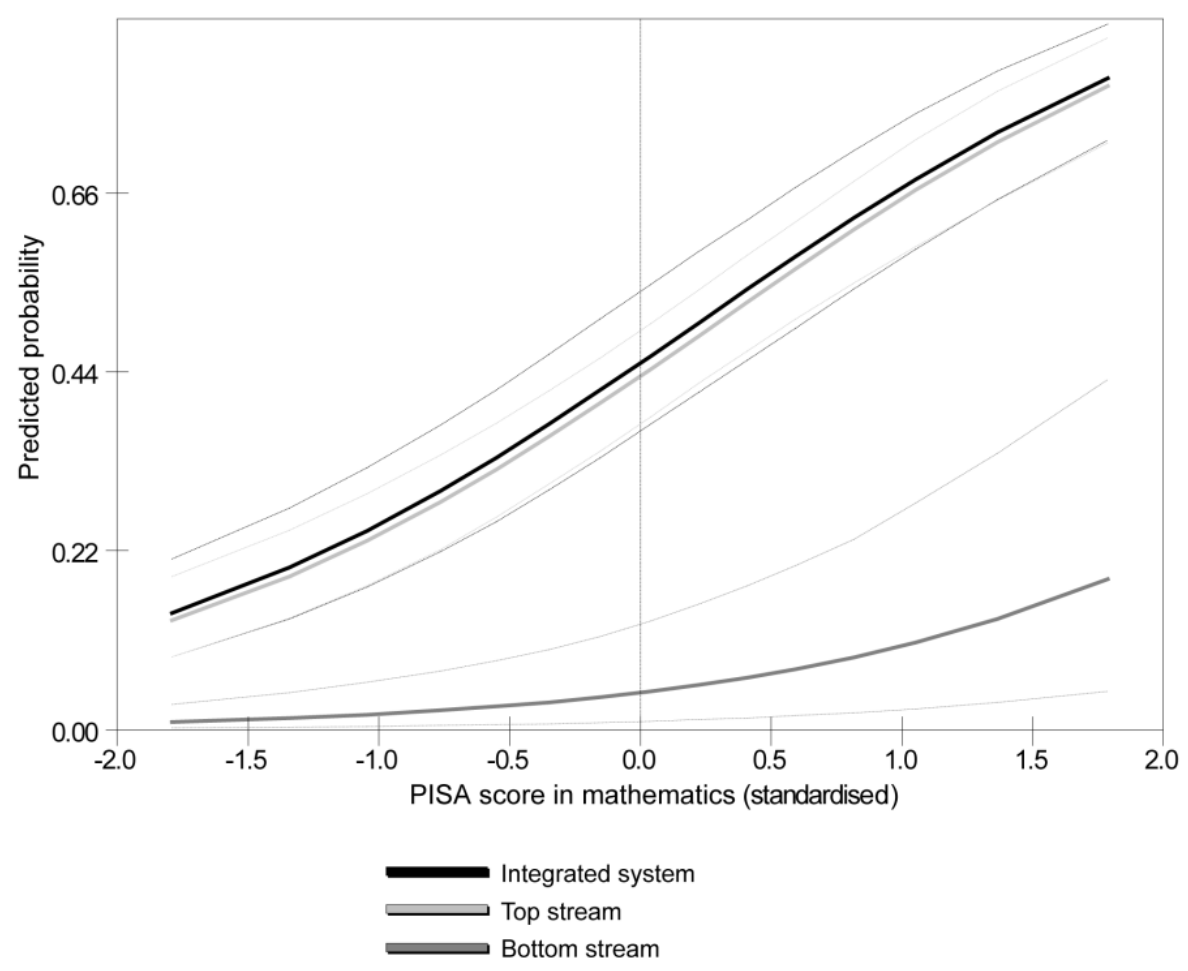

Figure 1. Predicted probability of being in a baccalaureate school, three years after the end of secondary 1 education, depending on the PISA score in mathematics and the modes of grouping students in classes in the last year of secondary 1 education (Model

$4 \mathrm{~b})$

Note: Computed by the authors.

The probability of being in a baccalaureate school is not significantly different between students from the top stream and those from the integrated system. On the other hand, students from the bottom stream always have a significantly lower probability of being in a baccalaureate school, irrespective of their PISA score in mathematics. For example, a student whose score is a standard deviation below average will only have a $2 \%$ chance of being oriented towards a baccalaureate school if they are in the bottom stream, whereas a student with exactly the same level of competence from the integrated system will have about $25 \%$ chance. This shows that being in the bottom stream in secondary 1 education almost totally excludes being oriented towards a baccalaureate school as the probability never exceed $20 \%$, even for students with the highest mathematics scores.

Models 4 and $4 \mathrm{~b}$ assume that the effects of the segmented and integrated systems are identical for all students, irrespective of class composition. We are going to modify this assumption to allow the effects of modes of grouping students to vary depending on class composition. We have first built model 4c (see table A2 in Appendix) which adds an interaction effect between the modes of grouping students and the average PISA score in mathematics per class. The aim is to estimate whether the effect of within-school academic segregation is different in the segmented and integrated systems. 


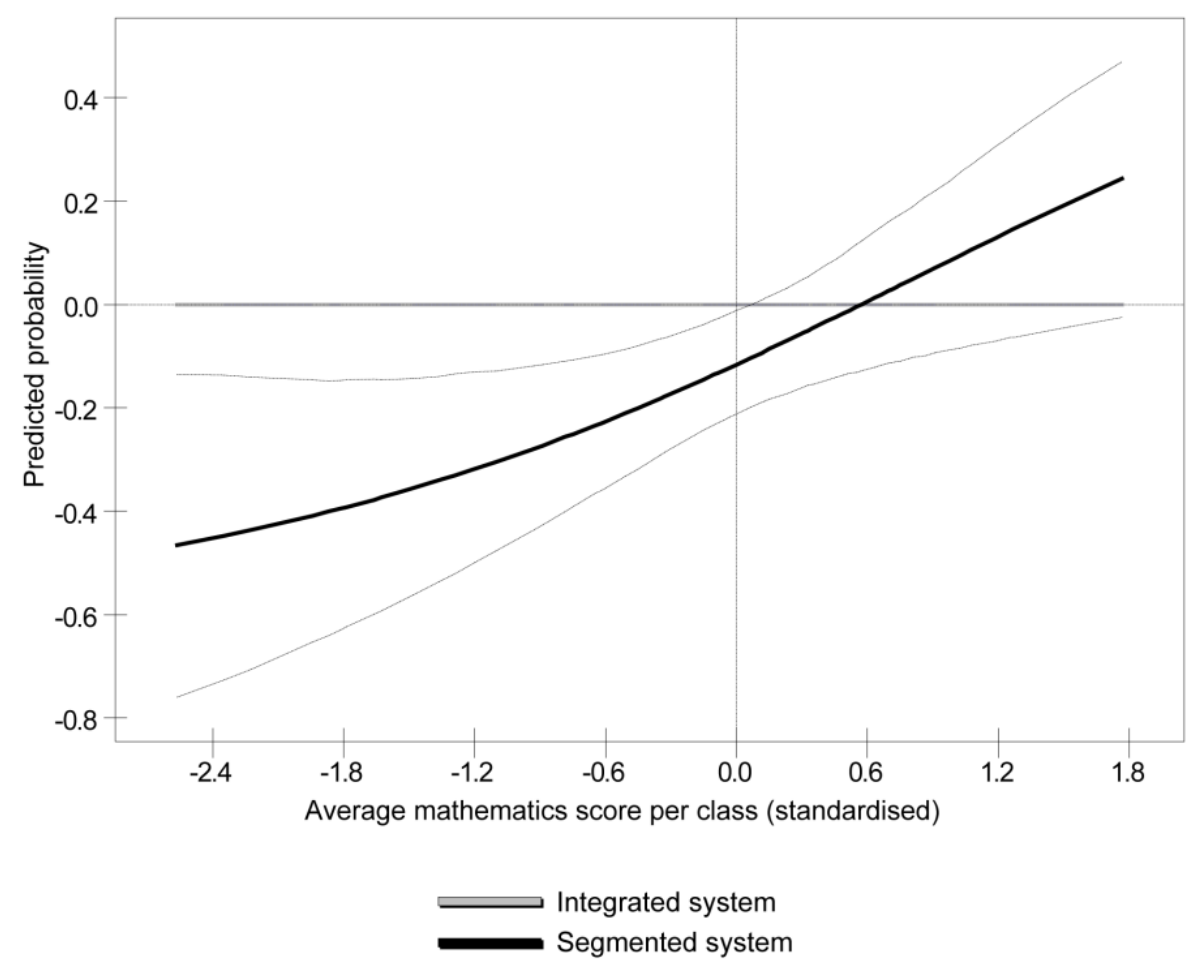

Figure 2. Predicted probability of being in a baccalaureate school, three years after the end of secondary 1 education, depending on the average PISA score in mathematics per

class and the modes of grouping students in classes in the last year of secondary 1 education (Model 4c)

Note: Computed by the authors.

Figure 2 shows the differences in predicted probability between the segmented and the integrated systems depending on the average PISA score in mathematics per class. As the integrated system is the reference, the predicted probability remains constant no matter the average mathematics score per class. In classes where the average score in mathematics is below average, students who are in the segmented system always have a lower probability of being in a baccalaureate school. The more the average score per class increases, the closer the predicted probabilities get to those observed in the integrated system. When the average score per class is above average, the $95 \%$ confidence interval indicates that the differences in probability are no longer significant. This means the segmented system tends to penalise students more strongly in classes where the average academic level is low, yet, in comparison with the integrated system, it does not provide any advantage for students in classes where the average level is high.

With model 4d (see table A2 in Appendix), an interaction effect between the modes of grouping students and the social and migratory composition of classes has been introduced. The aim is to estimate whether within-school social and migratory segregation has a different effect in the segmented and integrated systems. A significant interaction effect can be found for the average percentage of disadvantaged first-generation students per class: in the segmented system, each time the percentage of the first-generation students with a low ESCS per class increases by a standard deviation, the probability of being in a baccalaureate school decreases by $1.87(\mathrm{OR}=.534, \mathrm{p}<.001)$. This is illustrated in figure 3 , which shows the differences in predicted probabilities 
between the segmented system and the integrated system depending on the average percentage of disadvantaged first-generation students per class.

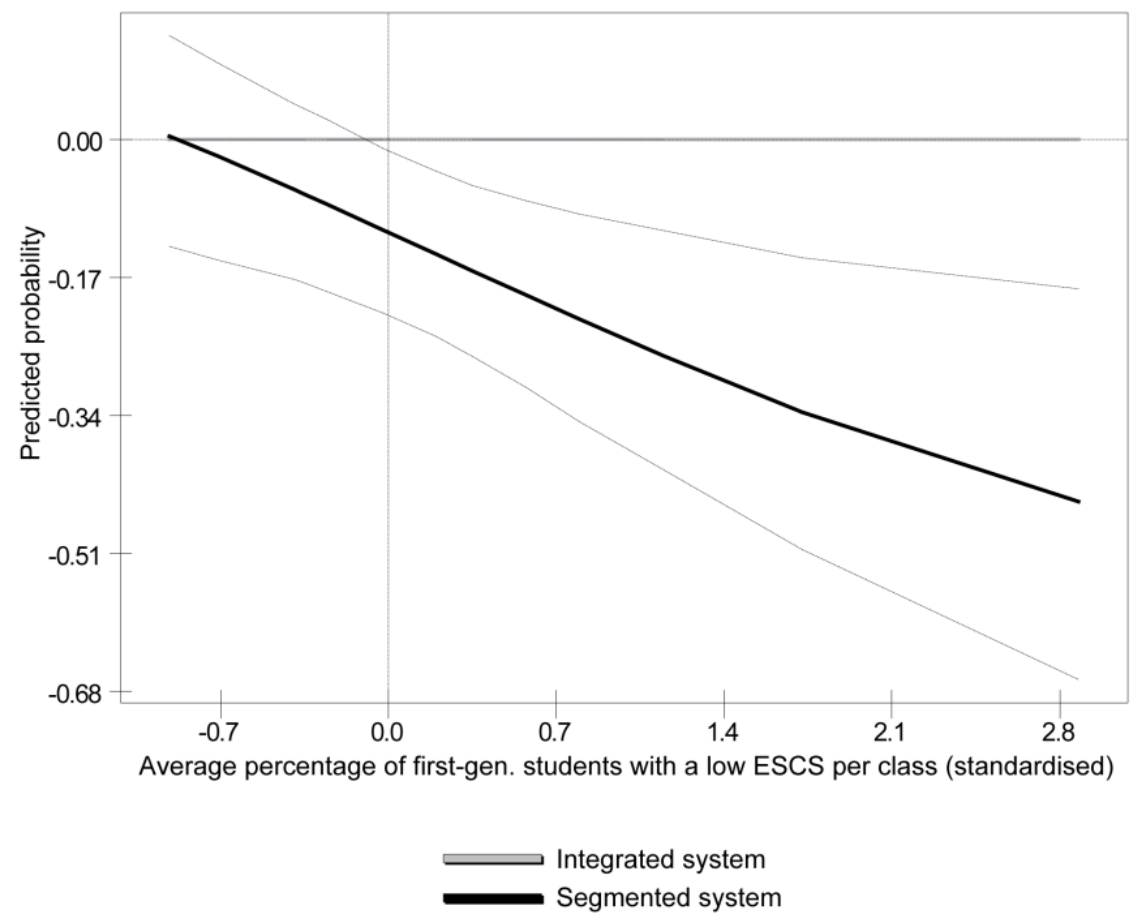

Figure 3. Predicted probability of being in a baccalaureate school, three years after the end of secondary 1 education, depending on the average percentage of first-generation students with a low ESCS per class and the modes of grouping students in classes in the last year of secondary 1 education (Model 4d)

Note: Computed by the authors.

The average percentage of disadvantaged first-generation students per class produces different effects in the segmented and integrated systems. When the percentage of disadvantaged first-generation students per class is below average, the probability of being in a baccalaureate school is not significantly different between the segmented and the integrated systems. However, when the percentage of disadvantaged first-generation students is above average, students from the segmented system are significantly less likely to be in a baccalaureate school. In other words, the segmented system produces more inequalities because students seem more sensitive to the effects of social and migratory composition of classes.

\section{Discussion}

Academic success does not only depend on the individual characteristics of students. It is also linked to the school context, and, in particular, the composition of the public in schools and classes. In the educational context described in this article, these compositional effects are mainly linked to the segmented system, which, by grouping students together in different classes according to their academic level, indirectly produces segregation depending on their social and migratory characteristics. The purpose of this article was to estimate the impact of different modes of grouping students and of within-school segregation in secondary 1 education on the way students are 
oriented in secondary 2 education. We carried out multilevel logistic regression analysis using longitudinal data on the education system in Geneva, which, when the data were collected, offered a dual system of both segmented and integrated classes. We initially questioned the role played by the modes of grouping students in classes. A negative effect of the segmented system was found: compared to the integrated system, students attending the segmented system are 1.6 times less likely to be in a baccalaureate school, three years after ending secondary 1 education. This negative effect of the segmented system appears to be mainly related to the bottom stream, where students are approximately 20 times less likely to be in a baccalaureate school. This means that, the bottom stream, far from fulfilling its official mission of helping students overcome their academic difficulties, instead contributes to selecting these students at the beginning of secondary 1 education, which greatly reduces their chances of being oriented to a baccalaureate school in secondary 2 education.

We then examined the effects of within-school segregation. We show that social and migratory segregation contributes to reinforcing inequalities between students: the likelihood of attending a baccalaureate school is much lower in classes with a higher percentage of native and second-generation students from a disadvantaged background. Finally, the relationship between the modes of grouping students in classes and academic, social and migratory segregation was analysed. The segmented system tends to penalise students more in classes where the level of competence is low and where the concentration of disadvantaged first-generation students is high. This means the segmented system appears to be both less effective than the integrated system -students have a lower probability of being oriented to a baccalaureate school- and also less equitable, as the negative effects of within-school segregation tend to be stronger. In other words, the segmented system seems to amplify the effects of within-school segregation: students whose schooling takes place in the most disadvantaged context are at a much greater disadvantage than their peers in the integrated system. Ultimately, the segmented system, as it was organised in Geneva up to 2011, questions the functioning of educational policies in terms of social justice, as the segmented system does not seem to be very conducive to equalising educational opportunities.

The findings of this study have to be seen in light of some limitations. The first is that inequalities are analysed during the transition from secondary 1 to secondary 2 education. However, research has shown that educational inequalities are already present from the very beginning of schooling and that they increase and accumulate throughout the school career (Duru-Bellat, 2007). Data that include measures of inequality in the early stages of schooling would allow a more precise estimation of the effect of modes of grouping. The second limitation is that our analysis focuses on the orientation towards baccalaureate schools. However, this is not the only way to access higher education. In Switzerland, students who follow a vocational track in secondary 2 education can obtain a Federal Vocational Baccalaureate which then gives access to universities of applied science. Research has shown that it is an important pathway to tertiary education, especially for students with a migrant background (for Albanian/Kosovan, former Yugoslavs, Portuguese and Turks in particular) (Murdoch et al., 2016). It would therefore be relevant to examine how the modes of grouping in secondary 1 education influence the orientation towards a vocational track.

These results lead to a more general reflection on the organisation of education systems and the policies to be implemented in order to reduce inequalities. The analysis of the 
orientations at the end of secondary 1 education in Geneva shows that the academic selection which takes place in secondary 1 education due to the streaming system is always a social and migratory selection. This produces strong polarisation in secondary 2 education, with, on one side, the baccalaureate schools which lead the academic and social 'elites' towards further education and on the other side, vocational education and training, where disadvantaged migrants and academically weaker students are clearly over-represented.

Research comparing segmented and integrated systems tends to indicate that in integrated systems, weaker students benefit greatly from being in classes with their stronger peers whilst the best students draw very few disadvantages from the situation. Our results obtained in the educational context of Geneva tend to agree with this: integrated systems contribute more to reducing inequalities.

Nevertheless, can one conclude that segmented systems systematically have a negative impact and subsequently, that it is pertinent to generalise integrated systems? Comparative analyses carried out on other Swiss cantonal education systems from the data collected in the PISA studies incites us to nuance this affirmation (Felouzis \& Charmillot, 2013). Indeed, cantons that use a segmented system produce very variable levels of inequality and cantons with an integrated system do not necessarily produce the least inequalities. However, these analyses have highlighted a very clear result: cantons with the most segregated educational systems, socially and academically speaking, are also the most unequal. The 'official' boundaries laid out for dividing segmented or integrated systems may not be sufficient to understand the true degree of school segregation that stems from them. It can therefore be argued that it is not simply the fact that students are split into segmented or integrated systems that is important, but also how these divisions operate in the reality of school life: social and migratory segregation. From a scientific standpoint, this implies that the debate cannot simply focus on the analysis of the respective merits of the segmented and the integrated systems concerning their effectiveness and their equity, insofar as there is sometimes a big difference between the official designation of the modes of grouping students and the way the grouping is undertaken in reality. It thus seems more pertinent to reason on the contributing factors, in a given context, that make certain ways of organising educational systems more effective and more equitable than others (teacher training, level of expectation in the class, recommended study plans for each stream, etc.). This would lead to new research perspectives, the object of which would be to analyse the real implementation of school policies and the role of the different public actors involved in their design and their application. This is the purpose of a current research project in which we aim to understand how the reform of secondary 1 education in Geneva is constructed and how it will be implemented.

\section{Acknowledgements}

We thank the Federal Office of Statistics (OFS-Office Fédéral de la Statistique) for providing us with the data from the PISA Suisse study. We thank Geneva Educational Research Department (SRED-Service de la Recherche en Éducation) for providing us with the Geneva schooling database. We would also like to thank our colleague, Carl Denecker, for his help reviewing the manuscript. 


\section{References}

Bickel, R. (2007). Multilevel analysis for applied research: it's just regression! The Guildford Press.

Brunello, G. \& Checchi D. (2007). Does school tracking affect equality of opportunity? New international evidence. Economic Policy 22(52), 781-861. https://doi.org/10.1111/j.14680327.2007.00189.x

Charmillot, S. (2013). Ségrégation et inégalités scolaires: Le cas de l'enseignement secondaire à Genève. Faculté de Psychologie et des Sciences de l'Éducation, Université de Genève.

Coleman, J. S., Ernest Q., Campbell, C. F., Hobson, J. M., McPartland, A. M., Mood, R. L., York, \& Weinfeld, F. (1966). Equality of educational opportunity. U.S. Department of Health, Education and Welfare.

Dumay, X. \& Dupriez, V. (2007). Does the school composition effect matter? Some methodological and conceptual considerations. Les Cahiers de Recherche du Girsef, 60, 1-29.

Duru-Bellat, M. (2007). Social inequality in French education. Extent and complexity of the issues. In R. Teese, S. Lamb, and M. Duru-Bellat (Eds.), International studies in educational inequality, theory and policy (pp. 337-356). Springer. https://doi.org/10.1007/978-1-4020-5916-2_12

Felouzis, G. \& Charmillot, S. (2013). School tracking and educational inequality: A comparison of 12 education systems in Switzerland. Comparative Education 49(2), 181-205. https://doi.org/10.1080/03050068.2012.706032

Felouzis, G., Charmillot, S., \& Fouquet-Chauprade, B. (2011). Les inégalités scolaires en Suisse et leurs déclinaisons cantonales: L’apport de l'enquête PISA 2003. Revue Suisse de Sociologie $37(1), 33-55$.

Felouzis, G., Fouquet-Chauprade, B., \& Charmillot, S. (2019). School segregation in France: The role of public policies and stakeholder strategies. In X. Bonal and C. Bellei (Eds.), Understanding school segregation. Patterns, causes and consequences of spatial inequalities in education (pp. 29-44). Bloomsbury. https://doi.org/10.5040/9781350033542.ch-002

Gamoran, A. (2010). Tracking and inequality: New directions for research and practice. In M. Apple, S. Ball, and L. Armando Gandin (Eds.), The Routledge international handbook of the sociology of education (pp. 213-228). Routledge.

Gamoran, A., Nystrand, M., Berends, M., \& Lepore, P. (1995). An organizational analysis of the effects of ability grouping. American Educational Research Journal, 32(4), 687-715. https://doi.org/10.3102/00028312032004687

Ganzeboom, H. B. G., De Graaf, P. M., \& Treiman, D. J. (1992). A standard international socioeconomic index of occupational status. Social Science Research, 21(1), 1-56. https://doi.org/10.1016/0049-089X(92)90017-B

Hallinan, M. T. (1994). School differences in tracking effects on achievement. Social Forces, 72(3), 799-820. https://doi.org/10.1093/sf/72.3.799

Hanushek, E. A. \& Woessmann, L. (2006). Does educational tracking affect performance and inequality? Differences- in-differences evidence across countries. The Economic Journal 116(510), 63-76. https://doi.org/10.1111/j.1468-0297.2006.01076.x

Hörner, W., Döbert, H., Reuter, L., \& von Kopp, B. (2015). The education systems of Europe. Springer. https://doi.org/10.1007/978-3-319-07473-3

James, D. R. \& Taeuber, K. E. (1985). Measures of segregation. Sociological Methodology, 15, 1-32. https://doi.org/10.2307/270845 
Jencks, C. \& Mayer, S. E. (1990). The social consequences of growing up in a poor neighborhood. In L. E. Lynn \& M. G. H. McGeary (Eds.), Inner-city poverty in the United States (pp. 348363). National Academy Press.

Lucas, S. R. (1999). Tracking inequality: Stratification and mobility in american high schools. Teachers College Press.

Lucas, S. R. \& Berends, M. (2002). Sociodemographic diversity, correlated achievement, and de facto tracking. Sociology of Education, 75(4), 328-348. https://doi.org/10.2307/3090282

Mickelson, R. A. (2003). When are racial disparities in education the result of racial discrimination? a social science perspective. Teachers College Record, 105(6), 1052-1086. https://doi.org/10.1111/1467-9620.00277

Monseur, C. \& Crahay, M (2008). Composition académique et sociale des établissements, efficacité et inégalités scolaires: Une comparaison internationale. Revue Française De Pédagogie, 164, 55-65. https://doi.org/10.4000/rfp.2128

Murdoch, J., Guégnard, C., Griga, D., Koomen, M., \& Imdorf, C. (2016). How do second-generation immigrant students access higher education? The importance of vocational routes to higher education in Switzerland, France, and Germany. Swiss Journal of Sociology 42(2), 245-265. https://doi.org/10.1515/sjs-2016-0011

Murillo, F. J. (2016). Midiendo la segregación escolar en América Latina. Un análisis metodológico utilizando el TERCE [Measuring the school segregation in Latin America. A methodological analysis using TERCE]. REICE. Revista Iberoamericana sobre Calidad, Eficacia y Cambio en Educación, 14(4), 33-60. https://doi.org/10.15366/reice2016.14.4.002

Murillo, F. J. \& Martínez-Garrido, C. (2019). Profiles of school segregation by socioeconomic status in Spain and its Autonomous Communities. RELIEVE, 25(1), 1-21. https://doi.org/10.7203/relieve.25.1.12917

Oakes, J. (2005). Keeping track: How schools structure inequality. Yale Univ. Press.

Padilla, E. \& Bazán A. (2016). Contextual, socioeconomic and cultural impacts on the outcomes of mexico in reading in PISA 2009. REICE. Ibero-American Journal on Quality, Effectiveness and Change in Education, 14(2), 79-95.

OECD. (2005). PISA 2003 technical report. OECD. https://doi.org/10.1787/9789264010543-en

OECD. (2013). PISA 2012 results: What makes schools successful? Resources, policies and practices (Volume $I V)$. OECD Publishing. https://doi.org/10.1787/9789264201156-en

Rumberger, R. W. \& Palardy, G. J. (2005). Does segregation still matter? The impact of student composition on academic achievement in high school. Teachers College Record, 107(9), 19992045. https://doi.org/10.1111/j.1467-9620.2005.00583.x

Schofield, J. W. (1995). Review of research on school desegregation's impact on elementary and secondary school students. In J. A. Banks \& C. A. MaGee Banks (Eds.), Handbook of research on multicultural education (pp. 597-617). Mac Millan.

Slavin, R. E. (1987). Ability grouping and student achievement in elementary schools: A bestevidence synthesis. Review of Educational Research, 57(3), 293-336.

https://doi.org/10.3102/00346543057003293

Slavin, R. E. (1990). Achievement effects of ability grouping in secondary schools: A best-evidence synthesis. Review of Educational Research, 60(3), 471-499. https://doi.org/10.3102/00346543060003471

Slavin, R. E. (1993). Ability grouping in the middle grades: Achievement effects and alternatives. Elementary School Journal, 93(5), 535-552. https://doi.org/10.1086/461739 
Snijders, T. A. \& Bosker, R. J. (2012). Multilevel analysis. An introduction to basic and advanced multilevel modeling. SAGE Publications.

UNESCO. (2006). International standard classification of education, ISCED 97. UNESCO.

van Ewijk, R. \& Sleegers, P. (2010a). The effect of peer socioeconomic status on student achievement: A meta-analysis. Educational Research Review, 5(2), 134-150.

https://doi.org/10.1016/j.edurev.2010.02.001

van Ewijk, R. \& Sleegers, P. (2010b). Peer ethnicity and achievement: A meta-analysis into the compositional effect. School Effectiveness and School Improvement, 21(3), 237-265. https://doi.org/10.1080/09243451003612671

Weinberg, M. (1975). The relationship between school desegregation and academic achievement: A review of the research. Law and Contemporary Problems, 39(2), 241-270. https://doi.org/10.2307/1191101

Woessmann, L. (2009). International evidence on school tracking: A review. Ifo Institute. 


\section{Appendix}

Table A1. Descriptive statistics for the variables included in the multilevel logistic regression models

\begin{tabular}{|c|c|c|c|c|c|c|}
\hline & & $\mathbf{N}$ & MIN. & MAX. & MEAN & SD \\
\hline \multirow{2}{*}{$\begin{array}{l}\text { Path in secondary } 2 \\
\text { education }\end{array}$} & Baccalaureate school & 3138 & 0.00 & 1.00 & 0.46 & 0.50 \\
\hline & Other path & 3138 & 0.00 & 1.00 & 0.54 & 0.50 \\
\hline \multirow{9}{*}{$\begin{array}{l}\text { Social and migratory } \\
\text { status }\end{array}$} & $\begin{array}{l}\text { Native students with a low } \\
\text { ESCS }\end{array}$ & 3095 & 0.00 & 1.00 & 0.14 & 0.34 \\
\hline & $\begin{array}{l}\text { Native students with a middle } \\
\text { ESCS }\end{array}$ & 3095 & 0.00 & 1.00 & 0.25 & 0.43 \\
\hline & $\begin{array}{l}\text { Native students with a high } \\
\text { ESCS }\end{array}$ & 3095 & 0.00 & 1.00 & 0.28 & 0.45 \\
\hline & $\begin{array}{l}\text { Second-gen. students with a } \\
\text { low ESCS }\end{array}$ & 3095 & 0.00 & 1.00 & 0.11 & 0.31 \\
\hline & $\begin{array}{l}\text { Second-gen. students with a } \\
\text { middle ESCS }\end{array}$ & 3095 & 0.00 & 1.00 & 0.06 & 0.23 \\
\hline & $\begin{array}{l}\text { Second- gen. students with a } \\
\text { high ESCS }\end{array}$ & 3095 & 0.00 & 1.00 & 0.04 & 0.19 \\
\hline & $\begin{array}{l}\text { First- gen. students with a low } \\
\text { ESCS }\end{array}$ & 3095 & 0.00 & 1.00 & 0.07 & 0.26 \\
\hline & $\begin{array}{l}\text { First- gen. students with a } \\
\text { middle ESCS }\end{array}$ & 3095 & 0.00 & 1.00 & 0.04 & 0.20 \\
\hline & $\begin{array}{l}\text { First- gen. students with a high } \\
\text { ESCS }\end{array}$ & 3095 & 0.00 & 1.00 & 0.02 & 0.15 \\
\hline \multirow{2}{*}{ Sex } & Girls & 3138 & 0.00 & 1.00 & 0.52 & 0.50 \\
\hline & Boys & 3138 & 0.00 & 1.00 & 0.48 & 0.50 \\
\hline \multirow{2}{*}{ Language spoken } & Other languages & 3138 & 0.00 & 1.00 & 0.32 & 0.47 \\
\hline & French & 3138 & 0.00 & 1.00 & 0.68 & 0.47 \\
\hline \multirow{2}{*}{ Years repeated } & Did repeat a year & 3105 & 0.00 & 1.00 & 0.13 & 0.34 \\
\hline & Did not repeat a year & 3105 & 0.00 & 1.00 & 0.87 & 0.34 \\
\hline Age & & 3138 & 12.00 & 17.00 & 14.30 & 0.55 \\
\hline PISA score in mathem & atics & 3138 & 205.36 & 763.08 & 515.95 & 83.66 \\
\hline \multirow{3}{*}{$\begin{array}{l}\text { Social and migratory } \\
\text { composition of classes }\end{array}$} & $\begin{array}{l}\text { Average percentage of native } \\
\text { students with a low ESCS per } \\
\text { class }\end{array}$ & 3138 & 0.00 & 0.40 & 0.14 & 0.09 \\
\hline & $\begin{array}{l}\text { Average percentage of second- } \\
\text { gen. students with a low ESCS } \\
\text { per class }\end{array}$ & 3138 & 0.00 & 0.50 & 0.11 & 0.10 \\
\hline & $\begin{array}{l}\text { Average percentage of first- } \\
\text { gen. students with a low ESCS } \\
\text { per class }\end{array}$ & 3138 & 0.00 & 0.45 & 0.08 & 0.08 \\
\hline \multicolumn{2}{|c|}{ Average percentage of boys per class } & 3138 & 0.18 & 0.77 & 0.48 & 0.11 \\
\hline \multicolumn{2}{|c|}{$\begin{array}{l}\text { Average percentage of students who repeated a year per } \\
\text { class }\end{array}$} & 3138 & 0.42 & 1.00 & 0.84 & 0.14 \\
\hline \multicolumn{2}{|l|}{ Average age of the class } & 3138 & 13.90 & 14.92 & 14.33 & 0.19 \\
\hline \multicolumn{2}{|c|}{ Average mathematics score per class } & 3138 & 381.67 & 600.06 & 512.26 & 47.46 \\
\hline \multicolumn{2}{|c|}{$\begin{array}{l}\text { Average score per class on the index of teacher-student } \\
\text { relations }\end{array}$} & 3138 & -1.07 & 0.57 & -0.25 & 0.36 \\
\hline
\end{tabular}




\begin{tabular}{|c|c|c|c|c|c|c|}
\hline \multicolumn{2}{|c|}{ Average score per class on the teacher support index } & 3138 & -1.63 & 0.72 & -0.28 & 0.54 \\
\hline \multicolumn{2}{|c|}{$\begin{array}{l}\text { Average score per class on the index of disciplinary } \\
\text { climate }\end{array}$} & 3138 & -1.67 & 1.42 & -0.33 & 0.47 \\
\hline \multirow{4}{*}{$\begin{array}{l}\text { Modes of grouping } \\
\text { students }\end{array}$} & Segmented system & 3138 & 0.00 & 1.00 & 0.83 & 0.37 \\
\hline & Top stream & 3138 & 0.00 & 1.00 & 0.65 & 0.48 \\
\hline & Bottom stream & 3138 & 0.00 & 1.00 & 0.18 & 0.38 \\
\hline & Integrated system & 3138 & 0.00 & 1.00 & 0.17 & 0.37 \\
\hline
\end{tabular}

Note: Computed by the authors.

Table A2. Probability of being in a baccalaureate school, three years after the end of secondary 1 education. Multilevel logistic regression analysis (odds-ratio). Model 4b, 4c, $4 \mathrm{~d}$

\begin{tabular}{|c|c|c|c|c|}
\hline & & $\begin{array}{l}\text { MODEL } \\
\text { 4B }\end{array}$ & $\begin{array}{c}\text { MODEL } \\
\text { 4C }\end{array}$ & $\begin{array}{l}\text { MODEL } \\
\text { 4D }\end{array}$ \\
\hline Constant & & 0.828 & 0.782 & 0.791 \\
\hline \multirow{9}{*}{ Social and migratory status } & $\begin{array}{l}\text { Native students with a low } \\
\text { ESCS }\end{array}$ & $0.387 * * *$ & $0.383 * * *$ & $0.384 * * *$ \\
\hline & $\begin{array}{l}\text { Native students with a } \\
\text { middle ESCS }\end{array}$ & $0.467 * * *$ & 0.466 & $0.465 * * *$ \\
\hline & $\begin{array}{l}\text { Native students with a high } \\
\text { ESCS }\end{array}$ & $0.287 * * *$ & $0.284^{* * *}$ & $0.289 * * *$ \\
\hline & $\begin{array}{l}\text { Second-gen. students with a } \\
\text { low ESCS }\end{array}$ & 0.738 & 0.715 & 0.708 \\
\hline & $\begin{array}{l}\text { Second-gen. students with a } \\
\text { middle ESCS }\end{array}$ & 0.707 & 0.716 & 0.709 \\
\hline & $\begin{array}{l}\text { Second- gen. students with a } \\
\text { high ESCS }\end{array}$ & $0.234 * * *$ & $0.222 * * *$ & $0.226 * * *$ \\
\hline & $\begin{array}{l}\text { First- gen. students with a } \\
\text { low ESCS }\end{array}$ & 1.261 & 1.081 & 1.116 \\
\hline & $\begin{array}{l}\text { First- gen. students with a } \\
\text { middle ESCS }\end{array}$ & 3.216 & 2.829 & 2.933 \\
\hline & $\begin{array}{l}\text { First- gen. students with a } \\
\text { high ESCS }\end{array}$ & ref. & ref. & ref. \\
\hline \multirow{2}{*}{ Sex } & Girls & $2.942^{* * * *}$ & $2.956^{* * * *}$ & $2.977^{* * *}$ \\
\hline & Boys & ref. & ref. & ref. \\
\hline \multirow{2}{*}{ Language spoken } & Other languages & 1.442 & 1.519 & 1.505 \\
\hline & French & ref. & ref. & ref. \\
\hline \multirow{2}{*}{ Years repeated } & Did repeat a year & $0.312^{* * *}$ & $0.322^{* * *}$ & $0.319^{* *}$ \\
\hline & Did not repeat a year & ref. & ref. & ref. \\
\hline Age & & 0.906 & 0.903 & 0.905 \\
\hline PISA score in mathematics & & $2.487 * * *$ & $2.509^{* * * *}$ & $2.512^{* * *}$ \\
\hline \multirow{2}{*}{$\begin{array}{l}\text { Social and migratory } \\
\text { composition of classes }\end{array}$} & $\begin{array}{l}\text { Average percentage of native } \\
\text { students with a low ESCS per } \\
\text { class }\end{array}$ & $0.763 * *$ & $0.748^{* *}$ & 0.89 \\
\hline & $\begin{array}{l}\text { Average percentage of } \\
\text { second-gen. students with a } \\
\text { low ESCS per class }\end{array}$ & 0.837 & 0.82 & 0.988 \\
\hline
\end{tabular}




\begin{tabular}{|c|c|c|c|c|}
\hline & $\begin{array}{l}\text { Average percentage of first- } \\
\text { gen. students with a low } \\
\text { ESCS per class }\end{array}$ & 1.204 & 1.135 & $1.716^{* *}$ \\
\hline \multicolumn{2}{|c|}{ Average percentage of boys per class } & 1.047 & 0.955 & 0.931 \\
\hline \multicolumn{2}{|c|}{$\begin{array}{l}\text { Average percentage of students who repeated a year per } \\
\text { class }\end{array}$} & 0.999 & 1.102 & 1.129 \\
\hline \multicolumn{2}{|l|}{ Average age of the class } & $0.702^{*}$ & 0.748 & 0.731 \\
\hline \multicolumn{2}{|c|}{ Average mathematics score per class } & 1.007 & 0.828 & $1.685^{* *}$ \\
\hline \multicolumn{2}{|c|}{$\begin{array}{l}\text { Average score per class on the index of teacher-student } \\
\text { relations }\end{array}$} & $1.231^{*}$ & 1.219 & 1.196 \\
\hline \multicolumn{2}{|c|}{ Average score per class on the teacher support index } & 0.844 & 0.868 & 0.862 \\
\hline \multicolumn{2}{|c|}{ Average score per class on the index of disciplinary climate } & 1.1 & 1.039 & 1.045 \\
\hline \multirow{4}{*}{ Modes of grouping students } & Segmented system & & $0.605^{*}$ & $0.604^{*}$ \\
\hline & Bottom stream & $0.048 * * *$ & & \\
\hline & Top stream & 0.942 & & \\
\hline & Integrated system & ref. & ref. & ref. \\
\hline \multicolumn{2}{|c|}{$\begin{array}{l}\text { Average mathematics score per class*Modes of grouping } \\
\text { students }\end{array}$} & & $2.438 * * *$ & \\
\hline \multicolumn{3}{|c|}{$\begin{array}{l}\text { Average percentage of native students with a low ESCS per } \\
\text { class*Modes of grouping students }\end{array}$} & & 0.788 \\
\hline \multicolumn{2}{|c|}{$\begin{array}{l}\text { Average percentage of second-gen. students with a low } \\
\text { ESCS per class*Modes of grouping students }\end{array}$} & & & 0.836 \\
\hline \multicolumn{2}{|c|}{$\begin{array}{l}\text { Average percentage of first-gen. students with a low ESCS } \\
\text { per class*Modes of grouping students }\end{array}$} & & & $0.566^{*}$ \\
\hline \multicolumn{2}{|c|}{$\begin{array}{l}\text { Proportion of total variance explained at the class level } \\
\text { (level 2) - ICC }\end{array}$} & 2.2 & 4.1 & 3.8 \\
\hline
\end{tabular}

Note: Computed by the authors.

\section{Brief CV of the authors}

\section{Samuel Charmillot}

$\mathrm{PhD}$ in Education Science from the University of Geneva, Switzerland. He is a lecturer and researcher at the Faculty of Psychology and Educational sciences of the University of Geneva, where he teaches statistics and quantitative methods. His main research interests focus on sociology of education, evaluation of educational policies, design and implementation of educational policies, distribution of educational opportunities and school segregation. His current research investigates the relationship between the organization of education systems, school segregation and educational inequalities. ORCID ID: https://orcid.org/O000-0003-1164-2212. Email: samuel.charmillot@unige.ch

\section{Georges Felouzis}

Full professor at the University of Geneva. His main research expertise is in sociology of educational policies and evaluation of educational systems. He teaches and publishes on efficiency and equity in educational systems, international comparisons in the field of 
education, sociology of educational policies, educational inequalities, school segregation theory and quantitative methods in social sciences. He founded and directs the Geneva group for educational policy analysis (GGAPE). He has published numerous articles and books on schooling and school inequalities such as in 2019, School segregation in France: inequality of origins and origin of inequalities In X. Bonal, C. Bellei \& A. Tarabini (Eds.). School segregation in Europe and Latin America. London: Bloomsbury Publishing (with Barbara Fouquet-Chauprade and Samuel Charmillot). His most recent work is the second edition of Les inégalités scolaires, Presses Universitaires de France, 2020. ORCID ID: https://orcid.org/0000-0002-2636-8001. Email: georges.felouzis@unige.ch 